\title{
Performance of Superconducting Cavities for CEBAF
}

\author{
Peter Kneigel, John Mammosser, Ganepeti Rso, Kenji Saito, Ron Sundelin \\ Continuous Electron Beam Accelerator Facility \\ 12000 Jefferson Avenue \\ Newport News, VA 23606
}

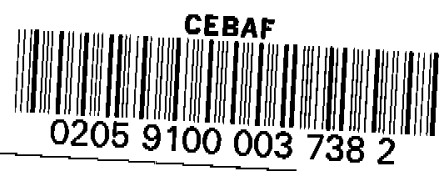

Abatract

The Continuous Electron Beami Accelerator Fecility (CEBAF) is presently under construction in Newport News, Virginia The accelerator consists of \%160 meters of 5-cell niobium eavities manufactured from high thermal conductivity niobium with RRR values > 250 .

After an initial six month period of first artiele manufacturing at a rate of 3 cavities per month, the full production rate of 12 cavities per month was reached in Oetober 1990. These cavities are chemically treated at CEBAF, assembled into hermetically sealed cavity pairs and tested in a vertical configuration prior to installation into the accelerator.

The performance of all eavities received from the manufacturer and tested at CEBAF has excegded CEBAF's design criteria for $Q$ value $>2.4 \times 10^{\circ}$ at $2 \mathrm{~K}$ and an accelerating gradient $\mathrm{E}$. $>5 \mathrm{MV} / \mathrm{m}$. $Q$ values as high as $10^{18}$ and accelecesting gradients of $\mathrm{E}$ ace $218 \mathrm{MV} / \mathrm{m}$ have been achieved.

\section{INTRODUCTION}

CEBAF will provide a low emittance electron beam with a current of $200 \mu \mathrm{A}$ and electron energies up to $4 \mathrm{GeV}$ for fundamental experimental studies in nuclear physies.[1]

It comprises two anti-parallel linear accelerators arranged as a racetrack. They each eonsist of 160 superconducting niobinm eavities of total ceelerating length of approximately 160 meters; 18 additional cavities of the same type are used in the injector. These cavities are assembled into hermetically sealed pairs|2|, which in torn are installed in a single helium vessel forming a crounit. Four such cryounits are joined into a eryomodule with a common insulation vacunm; the eryomodale represents the smallest wit that can be indepeadently cooled and installed or removed from the accelerator system.

The 5-cell cavities with an elliptical eross section and an active length of 0.5 meters are kept at $2 \mathrm{~K}$ by means of a $5 \mathrm{~kW}$ refrigerator, which is located in the center of the racetrock accelerator.

This work was supported by the U.S. Department of Energy under contract DE-AC05-84ER40150.
The eavities are excited in the accelerating mode at $1497.000 \mathrm{MHz}$ and are operated at an accelerating gradient of at least $5 \mathrm{MV} / \mathrm{m}$. At this gradient, each cavity will dissipate not more than 5.5 watts of RF power.

In order to schieve these low losses in the cavity walls and the high accelerating gradients, particular care has to be taken during the manufacturing processes for material and cavities and for the chemical processing and assembly of the cavities.

This paper deseribes CEBAF's approach for meeting the stringent requirements for quality of material and cavity manufacturing and discusses available results on cavity performance.

\section{MATERIAL REQUIREMENTS AND CAVITY FABRICATION}

For a long time, superconducting niobium eavities have been limited in their performanee by thermal instabilities in the cavity walls. As an important result of investigations into the canses of these instabilities, it was found that they ocear at loeal material defects and are stabilixed by improved thermal conductivity of the eavity material.

High thermal conductivity niobium, with $\lambda>$ $60 \mathrm{~W} / \mathrm{mK}$, has been chosen as the eavity material for areas of high electromagnetic fields in a eavity to sustain thermal instrabilities [3].

For parts of the eavities which have to sustain only moderate RF fields, reactor grade niobium with a thermal conductivity of $\sim 8-10 \mathrm{~W} / \mathrm{mK}$ is being used.

Other important parameters for the material include requirements for grain size, which influences the deep drawing eapability of cavity parts, and for the tensile properties. Simulation calculations using stres analysis codes on the real eavity shape under realistic load conditions resulted in a requirement of a yield strength greater than 13500 pai for the waveguide parts of the eavity and > 10700 psi for the cavity cells[4].

Table 1 summarizes CEBAF's material requirements as specified for resetor grade and RRR grade niobium.

For the accelerator system, CEBAF adopted the Cornell design of a cylindrical symmetric $1500 \mathrm{MHz}$ eavity with elliptical cross section, which had successfully been used for storsge ring application|5|. 


\begin{tabular}{|c|c|c|c|c|c|}
\hline Nobium & $\begin{array}{l}\text { Cavity } \\
\text { Part }\end{array}$ & $\mathbf{R R R}$ & $\begin{array}{l}\text { Grain } \\
\text { Sian }\end{array}$ & $\begin{array}{l}\text { Yield } \\
\text { Strength }\end{array}$ & Eloagation \\
\hline $\begin{array}{l}\text { Rentor } \\
\text { RRA }\end{array}$ & $\begin{array}{l}\text { Couplen } \\
\text { Flanget } \\
\text { Cells }\end{array}$ & $\begin{array}{l}=40 \\
>240\end{array}$ & $\begin{array}{l}\text { ASTM>6 } \\
\text { ASTM>6 }\end{array}$ & $\begin{array}{l}>13500 \\
>10700 \mathrm{poi}\end{array}$ & $\begin{array}{l}>25 \% \\
>25 \%\end{array}$ \\
\hline
\end{tabular}

The main features of this eavity are: shunt impedance $959 \mathrm{Q} / \mathrm{m}, \mathrm{E}, \mathrm{E} \mathrm{E}_{\mathrm{s}}=2.56$, H $/ \mathrm{E}=4.68 \mathrm{mT} / \mathrm{MV} / \mathrm{m}, \mathrm{G}=276$ ofm. Two of 茾ese cavities are assembled into a hermetically sealed pair. This is accomplished by adding a ceramic RF window|6| to the fundamental coupler flange, closing off the HOM waveguides with HOM loeda[7] and adding gate ralve assemblies at the beam pipe end of the cavity. In this concept, the inner cavity surfaces, which carry the RF current, are kept ander vacuum at all times after the initial assembly and the risk of contamination due to exposure to air during assembly operations is minimized.

CEBAF awarded a manufacturing contract for the 338 cavities needed for the accelerator to Interatom after a competitive bidding. process involving 5 qualified manufecturing companies. In addition, several cavities have been built "in-house" by a job shop approach.

The essential manufacturing steps (see details in Ref. [8], this conference) are specified in CEBAF's "Statement of Work" and following the mannfactaring drawings and processes developed at INS of Cornell University, are:

A) Deep drawing and machining of cavity components without deterioration in the quality of the material.

B) QA of the manufactured parts and removal of any kind of visual surface irregularities like seratehes, dent, voids, inclusions.

C) Final chemical cleaning of manufactured parts prior to electron beam welding.

D) Electron beam welding of the parts with full penetration welds, smooth weld appearance, free of Feld splatter and voids, in vacunm of $<5 x$ $10^{-6}$ Tors.

E) Leak checking of the finished eavity, tuning of the eavity to obtain the specified frequency and field profile flatness in the sccelerating mode and final muchining of the eavity to achieve the specified mechanical tolerances.

Strict adherence to these procedures conpled with good workmanship is a stringent requirement $t_{8}$ meet CEBAF's design specification of $Q>2.4 \times 10$ at $2 \mathrm{~K}$ and $5 \mathrm{MV} / \mathrm{m}$.

\section{CAVITY ASSEMBLY AND TESTING}

The performance of each cavity is tested prior to assembly into the accelerator. After a series of QA checks, the cavities are chemically polished in a buffered ehemical solution of nitric, hydrofluoric, and phosphoric seids, resulting in a removal of $\sim 60 \mu \mathrm{m}$. Thorough rinsing in oltrapure water, ultrasonic agitation, twofold rinsing with resgent grade methanol follows prior to the assembly of 2 eavities into a hermetically sealed pair inside a Class 100 cleanroom (Fig. 1).

After establiahing a vacuum of $<10^{-6}$ Torr in the hermetically sealed units, they are attached to cryogenic test system and cooled down to helium temperature in a vertical configuration. During this cooldown from room temperature to $4.2 \mathrm{~K}$, which typically is accomplished in 2 hours and reduces the danger of $Q$ degradation due to $\mathrm{Nb}-\mathrm{H}$ precipitation[9], the external magnetic field, which is present at the eryostat, is shielded to $<10 \mathrm{mG}$ (details in Ref. |10), this conference). Variable coexial to waveguide input conplers are part of the test system. They permit the excitation of each individual cavity at minimam reflected power.

The RF testing is done with a conventional manual RF system, which utilizes a VCO/amplirier circuit being phase locked to the cavity.

\section{TEST RESULTS AND DISCUSSION}

A typical performance characteristic of a cavity pair is shown in Fig. 2 where the $Q$, value is plotted vs the accelerating gredient.

To date, CEBAF has reecived 76 cavities from Interatom and 52 tests have been condueted on these cavities assembled to pairs. In addition, 16 cavities have been built "in-house" and 8 of these have been tested. The experience with these cavities/pairs can be summarized as follows.

A) All cavities exceeded CEBAF's design criteria of a $Q$ value $>2.4 \times 10^{\%}$ at $2 K$ and a gradient of $\mathrm{E}=5 \mathrm{MV} / \mathrm{m}$, in the first test except for 3 eavities. These failures in the early atages of the program were due to insufficient material remoral.

B) The average gradient of all above specification teats earried ont on Interatom cavities is presently $10 \mathrm{MV} / \mathrm{m}$, a factor of 2 above the design gradient.

In several tests, gradients > $15 \mathrm{MV} / \mathrm{m}$ have been measured and the highest gradient obtained in one cavity of a pair was $18 \mathrm{MV} / \mathrm{m}$. The gradients were always limited by excessive field emission loading.

C) The reciprocally averaged $Q$ value at $2 \mathrm{~K}$ and $5 \mathrm{MV} / \mathrm{m}$ is $7.6 \times 10^{\circ}$, factor of 3 higher than the design ralue.

D) A significant number of cavity pairs had to be reworked becunse of peripheral problems such as leaks or mechanical problems with the test setup. Leaks caused by external hardware have been identified and corrected, leaks at indium joints are 
presencly being reduced by improving the surface conditions and mechenical rigidity of the sealing surfaces.

E) The statistics of all cavity pair results are summarized in Fig. 3, where the maximum gradient is plotted vs the $Q_{0}$ value at $5 \mathrm{MV} / \mathrm{m}$.

\section{CONCLUSION}

CEBAF has successfully assembled and tested several cavity pairs with performance exceeding CDBAF's design criteria by a ggod margin.

$Q$ values in excess of $10^{1}$ and gradients as high as $18 \mathrm{MV} / \mathrm{m}$ have been schieved. This proves that the methods nsed for cavity fabrication and procesing are working and that supercondneting RF has mabured to a reliable technology.

Unanticipated mechanical problems with leaks in atexiliary systems point to the necessity of very stringent $Q A$ measures. The combinstion of superconductivity, vacuum and eryogenics at $2 \mathrm{~K}$ poses an extraordinary challenge to the successful implementation of a large scale system.

\section{ACKNOWLEDGEMENT}

The authors would like to acknowledge the support by the members of the Cavity Pair Assembly group: D. Beasley, I. Daniels, S. Downey, E. Hanson, A. Heidt, T. Howell, B. Lewis, J. Pauley, I. Turlington, and S. Williams.

J. Lilley's help in typing the menuscript is greatly appreciated.

\section{REFERENCES}

[1] H. Grander, Proceedings of the 1988 Linear Aceelerator Conference, CBBAF-Report-89-001, p. 3 ff, 1989.

[2] P. Kneisel, Proceedings of the 1987 Particle Accelerator Conference, 87CH2387-9, 1893, 1987.

[3] H. Piel, Proceedings of the Workshop on RF Superconductivity, Karlaruhe, West Germeny, July 2 - 4, KEK Report 3019, p. 85, H. Padamsee, ibid, p. 145, 1980.

(4) M. Wiseman and L. Harwood, CEBAF Technical Note TN\#0145, July, 1989.

[5] R. Sundelin, et.al., IEEE Trans. Nucl. Sei. NS32, 3570, 1985.

[6] L. Phillipa, private communication.

[7] I. Campisi, private communication.

[8] M. Dzenus, H. Iversen, M. Peiniger, M. Kiehlmann, this conference, paper \#PTP4.

[9] e.g. K. Saito, P. Kneisel, this conference, paper \#PTP3.

[10] C. Reece, J. Susta, T. Powers, B. Almeida, this conference, peper \#PRA66.

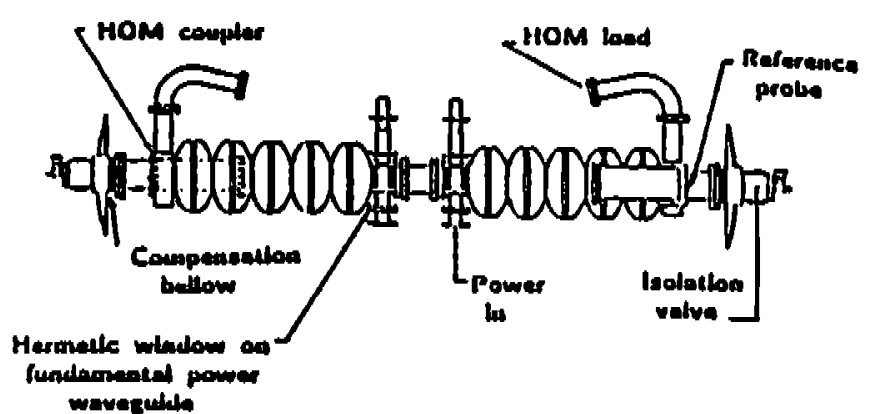

Fig 1.: Cavity Pair

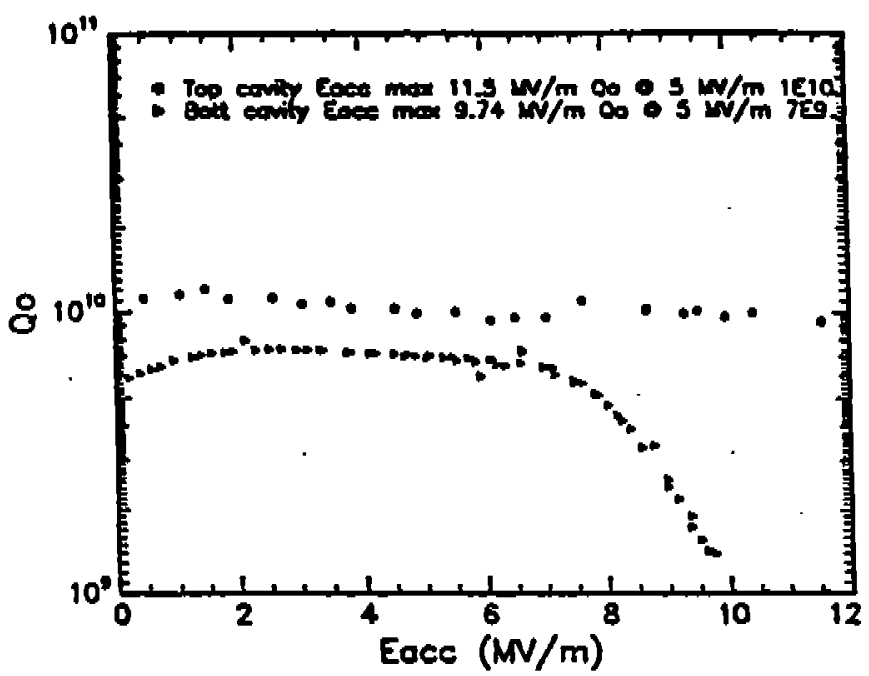

Fig. 2: Typical $Q_{Q}$ vo $E_{\text {aec }}$ for a Cavity Pair

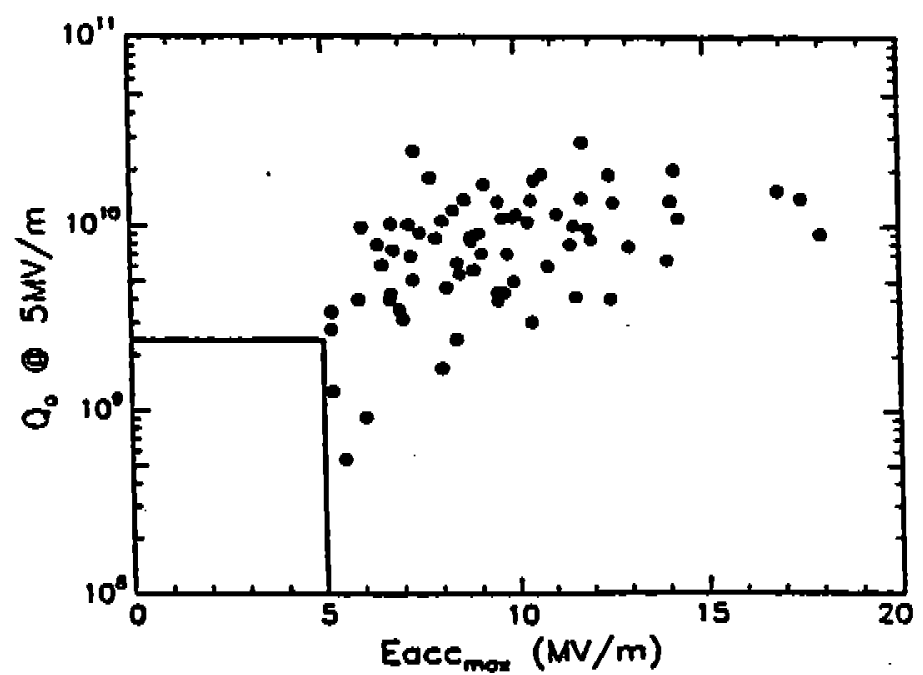

Fig. 3: Summary of Test Results on Cavity Pairs 